\title{
Polyphase low-grade metamorphism of the Ingleton Group, northern England, UK: a case study of metamorphic inversion in a mudrock succession
}

\author{
S. J. KEMP* \& R. J. MERRIMAN \\ British Geological Survey, Sir Kingsley Dunham Centre, Keyworth, Nottingham NG12 5GG, UK
}

(Received 30 April 2008; accepted 14 July 2008; First published online 14 November 2008)

\begin{abstract}
A series of boreholes in Horton Quarry, northwest Yorkshire (Horton-in-Ribblesdale Inlier) penetrated mudstones and slates belonging to the Austwick Formation (Windermere Supergroup) overlying laminated mudstones of the Ingleton Group. Illite (IC) and chlorite (ChC) crystallinity measurements indicate a metamorphic inversion between the two groups of mudrocks. The Windermere Supergroup mudrocks are mostly in the high anchizone or epizone, whereas the Ingletonian samples are lower grade in terms of IC, and are mostly deep diagenetic zone or low anchizone. Hence younger strata at higher grades rest on older strata at lower grades, creating a metamorphic inversion. Ingletonian slates exposed at Pecca Falls on the River Twiss show epizonal and anchizonal IC values, and greywacke samples from Ingleton Quarry contain pumpellyite. This suggests that grade in the Ingletonian may increase to the NW from the Horton to Ingleton inliers. K-white mica $b$ cell dimensions show further differences between the Ingleton Group and the Windermere Supergroup. The Ingletonian samples are characterized by low $b$ cell values (8.989-9.035, mean 9.007 $\AA$ ), whereas the Windermere Supergroup has higher values in the range 9.022-9.034, mean 9.027 $\AA$. The Windermere Supergroup values are similar to those recorded from the Windermere Supergroup of the southern Lake District, and Lower Palaeozoic rocks from the Scottish Southern Uplands, and are consistent with metamorphism in a low heat flow, convergent geotectonic setting. The Ingletonian $b$ cell values suggest metamorphism in a higher heat flow setting, most likely an extensional basin. The metamorphic inversion at Horton and differences in K-white mica $b$ cell dimensions suggest that the Ingleton Group and Windermere Supergroup strata evolved in different geotectonic settings and record two separate metamorphic events. The discovery of the metamorphic inversion at Horton provides further evidence in favour of an Ordovician rather than Neoproterozoic depositional age for the controversial Ingleton Group.
\end{abstract}

Keywords: Ingleton Group, Windermere Supergroup, low-grade metamorphism, clay minerals, illite crystallinity, metamorphic inversion.

\section{Introduction}

The Ingleton Group is a tightly folded sequence of mudstone, wacke and sporadic conglomerate of possible Precambrian or Early Ordovician age that crops out within the Craven inliers at Ingleton and in Ribblesdale, northwest Yorkshire (Soper \& Dunning, 2005; Williamson, 2005). The group is unconformably overlain by strata assigned to the Windermere Supergroup, a series of late Ordovician shelf deposits succeeded by lower Silurian hemipelagic rocks and a foreland basin sequence of thick, Upper Silurian turbidites (Kneller, King \& Bell, 1993; Kneller et al. 1994).

Despite the limited outcrop of the Ingleton Group, extensive research has been focused on these 'ancient rocks', stretching from the first description of the classic unconformity at Thornton Force (Playfair, 1802) to the recent details of their structure and sequence (Soper \& Dunning, 2005, and references therein) and age (Dodson \& Robinson, 2006). This is

*Author for correspondence: sjk@bgs.ac.uk the first detailed study of their burial and metamorphic history.

The study is based on changes in clay minerals that take place at temperatures up to approximately $300{ }^{\circ} \mathrm{C}$ during sedimentary basin development and sediment burial. Clay minerals undergo diagenetic and very low-grade metamorphic reactions, so that unlithified clays and muds are sequentially converted to lithified mudstone, shale and slate. Hower et al. (1976), in their seminal work on Tertiary shales from the United States Gulf Coast, were the first to note that mudrocks formed during burial commonly display predictable patterns of change in mineral assemblages that are produced by a series of reactions and can be used to indicate their conditions of formation. The most commonly described reaction series is the transformation of smectite to muscovite via a series of metastable intermediate products (e.g. Moore \& Reynolds, 1997; Środoń, 1999). These generally irreversible reactions are characterized by increases in crystal size (thickness), and decreases in crystal defect densities, lattice strain and compositional variability as the system becomes progressively better ordered (Peacor, 1992). 


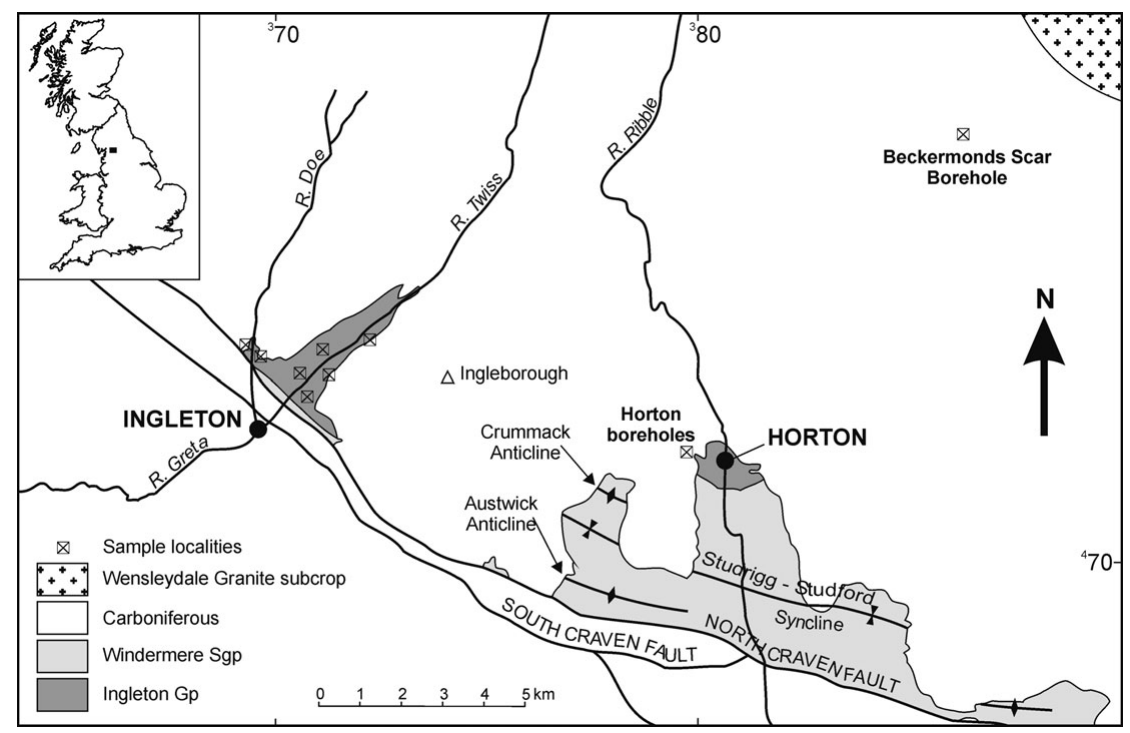

Figure 1. Location map for the Craven inliers (modified from Arthurton, Johnson \& Mundy, 1988), indicating structure and sample localities. Co-ordinates used are British National Grid, $100 \mathrm{~km}$ grid square SD.

Progress in the clay mineral reaction series as a measure of maturity and metamorphic grade of pelitic samples has been routinely studied using Xray diffraction (XRD) analyses to determine clay mineral assemblages, and in particular the Kübler index of illite 'crystallinity' (KI $\Delta^{\circ} 2 \theta$; e.g. Merriman \& Frey, 1999) in dioctahedral phyllosilicates. Four zones are most commonly used to characterize patterns in very low-grade metapelitic sequences: deep diagenetic zone (KIs $>0.42 \Delta^{\circ} 2 \theta$ ); low anchizone (0.30-0.42 $\left.\Delta^{\circ} 2 \theta\right)$; high anchizone $\left(0.25-0.30 \Delta^{\circ} 2 \theta\right)$ and epizone $\left(<0.25 \Delta^{\circ} 2 \theta\right)$. Chlorite crystallinity measurements using either the $14 \AA\left(\mathrm{ChC}_{001}\right)$ or the $7 \AA\left(\mathrm{ChC}_{002}\right)$ XRD peaks have been less widely used to determine reaction progress in trioctahedral phyllosilicates. Árkai (1991) suggested anchizonal limits of $\mathrm{ChC}_{001}=0.31-$ $0.43 \Delta^{\circ} 2 \theta$ and $\mathrm{ChC}_{002}=0.26-0.33 \Delta^{\circ} 2 \theta$. Reaction progress in clay minerals in relation to changes observed in organic materials has been used to construct a Basin Maturity Chart summarizing these depth-dependent changes (Merriman \& Kemp, 1996).

Measurement of the K-mica $b$ cell dimension, which is dependent on the degree of phengite substitution, has been related to the pressure conditions at the time of formation/recrystallization of the mica in the rock. Guidotti \& Sassi (1986) established a semiquantitative relationship between $b$ cell dimension and the metamorphic pressure gradient: $b$ values lower than $9.000 \AA$ are typical of low pressure and values higher than $9.040 \AA$ of high pressure facies metamorphism. The presence of detrital micas in subgreenschist facies may limit the use of the technique in deep diagenetic rocks (Padan, Kisch, \& Shagam, 1982).

The presence of the Ingleton Group/Windermere Supergroup unconformity and a detected metamorphic inversion in boreholes at Horton Quarry presented a rare opportunity to study polyphase alteration in rocks that preserve the lowest grades of metamorphism. In this paper we show how the techniques available for studying low temperature $\left(<300{ }^{\circ} \mathrm{C}\right)$ reactions in clay minerals can be used to model the burial and deformation history of sedimentary basins that now form part of the British Caledonides.

\section{Geological setting}

The Ingleton Group, with an exposed thickness of at least $3 \mathrm{~km}$, crops out in two of the Craven inliers at Ingleton and in Ribblesdale (Fig. 1). In the west, at Ingleton, it lies directly below the Carboniferous cover, whereas an increasing thickness of Windermere Supergroup strata intervenes to the east and produces a 'double unconformity' in the Ribblesdale Inlier. Here, the Ingleton Group is poorly exposed in a small area around Horton-in-Ribblesdale, but boreholes drilled in Horton Quarry penetrated the Ingleton Group beneath the Wenlock-Ludlow Austwick Formation (Windermere Supergroup); both stratigraphical units were sampled for this study. A more extensive subcrop had been revealed previously by the identification of Ingleton Group rocks in Beckermonds Scar Borehole [SD 88SE/1, SD 864802 ], located some $10 \mathrm{~km}$ to the NE of Horton and within the contact aureole of the concealed Wensleydale Granite. A single palynological sample from the borehole indicated an Early Ordovician depositional age (Wilson \& Cornwell, 1982). This biostratigraphical age is in close agreement with a $\mathrm{Rb}-\mathrm{Sr}$ radiometric age (recalculated with the 1977 decay constant, with a $95 \%$ confidence limit) of $494 \pm 18 \mathrm{Ma}$ obtained by O’Nions et al. (1973).

Soper \& Dunning (2005) recorded five lithofacies in the Ingleton Group, including medium- to thick-bedded sandstone, thin-bedded sandstone-siltstone--mudstone, laminated siltstone-mudstone, gravel-grade greywacke and massive sand-grade greywacke. They formally 
Table 1. Sample details, whole-rock mineralogies and K-white mica $b$ cell dimensions for the Horton Quarry borehole samples

\begin{tabular}{lcrll}
\hline Sample no. & Horton borehole & Depth $(\mathrm{m})$ & \multicolumn{1}{c}{ Stratigraphy } & \multicolumn{1}{c}{$\begin{array}{c}\text { K-white mica } b \\
\text { cell dimension }(\AA)\end{array}$} \\
\hline RJM915 & BH5 & 26.15 & Austwick Fm., Windermere Sgp & qtz, musc, chl, alb, dolom, pyr \\
RJM916 & BH5 & 96.10 & Austwick Fm., Windermere Sgp & qtz, musc, chl, alb, calc, dolom, pyr \\
RJM917 & BH5 & 128.60 & Austwick Fm., Windermere Sgp & qtz, musc, chl, alb, calc, dolom, pyr \\
RJM918 & BH3 & 67.66 & Austwick Fm., Windermere Sgp & qtz, musc, chl, alb \\
RJM919 & BH3 & 99.42 & Austwick Fm., Windermere Sgp & qtz, musc, chl, alb, calc, dolom, pyr \\
RJM920 & BH3 & 75.42 & Austwick Fm., Windermere Sgp & qtz, musc, chl, alb, dolom, pyr \\
RJM921 & BH2 & 107.19 & Ingleton Gp & qtz, musc, chl, alb \\
RJM922 & BH2 & 106.10 & Ingleton Gp & qtz, musc, chl, alb \\
RJM923 & BH2 & 48.00 & Ingleton Gp & qtz, musc, chl, alb, ?hem \\
RJM924 & BH4B & 108.20 & Ingleton Gp & qtz, musc, chl, alb \\
RJM925 & BH4B & 66.35 & Ingleton Gp & qtz, musc, chl, alb, hem \\
RJM926 & BH6 & 55.60 & Ashgill/Llandovery & qtz, musc, chl, alb, dolom \\
\hline
\end{tabular}

qtz - quartz; musc - muscovite; chl - chlorite; alb - albite; dolom - dolomite; calc - calcite; pyr - pyrite; hem - hematite; K-feld - K-feldspar.

defined the group as undivided greywackes $(>2550 \mathrm{~m})$ followed by the Baxengill ( $>220 \mathrm{~m})$, Pecca $(45-80 \mathrm{~m})$ and Skirwith ( $>150 \mathrm{~m}$, top not seen) formations.

Fold style in the Ingleton Group is tight, inclined and predominantly isoclinal, in marked contrast to the open fold style of the overlying and fossiliferous Windermere Supergroup, and indicates two periods of folding (Leedal \& Walker, 1950). A single slaty cleavage is present in the Ingleton Group which strikes parallel to that found in the overlying Ashgill-Ludlow strata of the Windermere Supergroup. Hence Soper \& Dunning (2005) concluded that the cleavage in the Ingleton Group is definitely Acadian (late Early Devonian: Merriman et al. 1995), whereas a beddingparallel fissility found in some fine-grained lithologies may be an earlier burial compaction fabric.

Two types of mafic minor intrusions were emplaced in the Ingleton Group. A thin metadolerite dyke, $<1 \mathrm{~m}$ wide, cuts the Pecca Formation in the old slate workings [SD 7034 7443] and then appears to split into two dykes, each less than $0.5 \mathrm{~m}$ thick, that cross the gorge of the River Doe [SD 7043 7435]. Based on their degree of alteration and fabric development, discussed below, Soper \& Dunning (2005) suggested that these intrusions were emplaced prior to the folding of the Ingleton Group. Two lamprophyre (kersantite) dykes are recorded by Soper \& Dunning (2005). One of the dykes, now exposed in Skirwith Quarry, is $1.4 \mathrm{~m}$ wide and shows a spaced planar fabric in its margins, subparallel with the cleavage in the enclosing Ingleton Group rocks. The lamprophyres are probably members of a suite of K-lamprophyres emplaced in northern England and Scotland during the Early Devonian (Nixon, Rex \& Condliffe, 1984), and they probably pre-date the Acadian deformation.

Provenance studies based on quartz-feldsparlithoclast discriminant diagrams (Soper \& Dunning, 2005, Fig. 13) indicate that the Ingleton Group was derived from a continental volcanic arc. The discriminant plots indicate the similarity of the Ingleton Group and the Charnian Supergroup, whereas the Skiddaw Group greywackes, which have been tentatively correlated with the Ingleton Group, plot separately within a 'quartzose recycled orogen'. $\mathrm{Nd}$ model ages for the Ingleton Group (1.18-1.23 Ga) also differ from those obtained from the Skiddaw Group (min. 1.44 Ga) but fall in the range of the Uriconian-derived Longmynd sediments (1.04$1.48 \mathrm{Ga}$ ) (O’Nions, Hamilton \& Hooker, 1983; Davies, Gledhill \& Hawkesworth, 1985). Hence Soper \& Dunning (2005) suggested a possible late Neoproterozoic Avalonian inter-arc setting. An alternative Early Ordovician depositional age is indicated by a more recent $\mathrm{Rb}-\mathrm{Sr}$ study by Dodson \& Robinson (2006). This study of higher-grade slates from Ingleton, rather than the lower-grade samples examined by O'Nions et al. (1973), produced an isochron age of $465 \pm 10 \mathrm{Ma}$ (95\% confidence level), which may relate to either a metamorphic or diagenetic interpretation. If this represents a metamorphic age, then it indicates an early Arenig deformation of the Ingleton Group, a possibility also considered by Soper \& Dunning (2005). However, until further palynological research is completed, a pre-Ordovician age for the Ingleton Group cannot be discounted.

\section{Samples}

Pelitic samples examined in this study were collected from a suite of boreholes drilled in Horton Quarry by Hanson Aggregates (SD 7950 7240, Table 1), and from outcrop and quarries along the rivers Twiss and Doe, Ingleton (Fig. 1, Table 2). Further samples from the Ingleton river sections, numbered MPA, were sampled from materials held in the BGS Palaeontological Collection (Table 2).

The laboratory methods employed are detailed in Appendix 1.

\section{Mineralogy}

Ingleton Group samples from the Horton boreholes are predominantly composed of quartz, $2 M_{1}$ muscovite, $1 M_{I b b}$ ferroan clinochlore, albite \pm hematite (Table 1). Muscovite and chlorite polytypes were identified using the criteria specified by Grathoff \& Moore (1996) and Bailey (1987), respectively. Outcrop samples have similar compositions with the addition of sporadic traces of calcite, K-feldspar and pyrite (Table 2). 
Table 2. Sample details, whole-rock mineralogies and K-white mica $b$ cell dimensions for the Ingleton outcrop samples

\begin{tabular}{|c|c|c|c|c|c|}
\hline Sample no. & Location (Ingleton) & Grid reference & Stratigraphy & Whole rock mineralogy & $\begin{array}{l}\text { K-white mica } b \text { cell } \\
\text { dimension }(\AA)\end{array}$ \\
\hline RJM730 & Road cutting at quarry entrance & SD 70657420 & Pecca Fm. & qtz, musc, chl, alb & 9.005 \\
\hline RJM731 & Pecca Falls, River Twiss & SD 69507480 & $\begin{array}{l}\text { Undivided } \\
\text { greywackes }\end{array}$ & qtz, musc, chl, alb, calc & 8.992 \\
\hline RJM927 & Old slate quarry, River Doe & SD 70257420 & Skirwith Fm. & qtz, musc, chl, alb & 9.001 \\
\hline RJM929 & Old slate quarry, River Doe & SD 70307435 & Skirwith Fm. & qtz, musc, chl, alb & 9.002 \\
\hline RJM1070 & Old slate quarry, River Doe & SD 7018174195 & Skirwith Fm. & qtz, musc, chl, alb & 8.993 \\
\hline RJM1071 & Below Snow Falls, River Doe & SD 7030674254 & Skirwith Fm. & qtz, musc, chl, alb, pyr & 9.018 \\
\hline RJM1073 & Old slate quarry, River Doe & SD 7038274419 & Pecca Fm. & qtz, musc, chl, alb, K-feld & 8.999 \\
\hline RJM1076 & Below Beezley Falls, River Doe & SD 7052974599 & Baxengill Fm. & qtz, musc, chl, alb & 9.004 \\
\hline RJM1077 & Quarry, B6255 & SD 7202875401 & Pecca Slate Fm. & qtz, musc, chl, alb & 9.035 \\
\hline MPA2242 & Above Thornton Force, River Twiss & SD 69607540 & Ingleton Gp & qtz, musc, chl, alb, hem & 9.001 \\
\hline MPA2243 & Above Thornton Force, River Twiss & SD 69607540 & Ingleton $\mathrm{Gp}$ & qtz, musc, chl, alb & 9.002 \\
\hline MPA2245 & Above Thornton Force, River Twiss & SD 69607540 & Ingleton $\mathrm{Gp}$ & qtz, musc, chl, alb, hem & 9.001 \\
\hline MPA2260 & Footpath, Pecca Falls, River Twiss & SD 69527490 & Ingleton $\mathrm{Gp}$ & qtz, musc, chl, alb & 9.030 \\
\hline MPA2262 & Footpath, Pecca Falls, River Twiss & SD 69527490 & Ingleton Gp & qtz, musc, chl, alb, hem & 9.016 \\
\hline MPA2263 & Pecca Falls footbridge, River Twiss & SD 69527486 & Ingleton $\mathrm{Gp}$ & qtz, musc, chl, alb & 8.998 \\
\hline MPA2265 & Pecca Quarry, River Twiss & SD 69527486 & Ingleton $\mathrm{Gp}$ & qtz, musc, chl, alb, calc & 8.989 \\
\hline MPA2275 & Above Snow Falls, River Doe & SD 70307438 & Ingleton $\mathrm{Gp}$ & qtz, musc, chl, alb, K-feld & 9.013 \\
\hline MPA2279 & Above Snow Falls, River Doe & SD 70347439 & Ingleton Gp & $\begin{array}{l}\text { qtz, musc, chl, alb, K-feld, } \\
\text { calc, pyr }\end{array}$ & 8.996 \\
\hline MPA2281 & Lower Baxengill Gorge, River Doe & SD 70437448 & Ingleton Gp & $\begin{array}{l}\text { qtz, musc, chl, alb, } \\
\text { K-feld, hem }\end{array}$ & 9.011 \\
\hline MPA2284 & Below Beezley Falls, River Doe & SD 70537459 & Ingleton $\mathrm{Gp}$ & qtz, musc, chl, alb, K-feld & 8.995 \\
\hline MPA2285 & Below Beezley Falls, River Doe & SD 70547465 & Ingleton $\mathrm{Gp}$ & qtz, musc, chl, alb, calc & 8.999 \\
\hline MPA2290 & Above Beezley Falls, River Doe & SD 70597480 & Ingleton $\mathrm{Gp}$ & qtz, musc, chl, alb, K-feld & 9.004 \\
\hline
\end{tabular}

qtz - quartz; musc - muscovite; chl - chlorite; alb - albite; dolom - dolomite; calc - calcite; pyr - pyrite; hem - hematite; K-feld - K-feldspar.

Table 3. Clay mineralogy, Kübler indices, chlorite crystallinities and metapelitic zones for the Horton Quarry borehole samples

\begin{tabular}{|c|c|c|c|c|c|c|c|}
\hline Sample no. & $\begin{array}{c}\text { Horton } \\
\text { borehole }\end{array}$ & Depth (m) & $<2 \mu$ m clay mineralogy & $\begin{array}{c}\text { Kübler Index } \\
\left(\mathrm{KI}, \Delta^{\circ} 2 \theta\right)\end{array}$ & $\begin{array}{l}\text { Metapelite Zone } \\
\text { (KI) }\end{array}$ & $\begin{array}{c}\text { Chlorite } \\
\text { crystallinity } \\
\left(\mathrm{ChC}_{002}, \Delta^{\circ} 2 \theta\right)\end{array}$ & $\begin{array}{l}\text { Metapelite Zone } \\
\quad\left(\mathrm{ChC}_{002}\right)\end{array}$ \\
\hline RJM915 & $\mathrm{BH} 5$ & 26.15 & $\mathrm{~K}$-mica, $\mathrm{Fe} / \mathrm{Mg}$ chlorite & 0.25 & High Anchizone & 0.22 & Epizone \\
\hline RJM916 & BH5 & 96.10 & $\mathrm{~K}$-mica, Fe/Mg chlorite & 0.24 & Epizone & 0.21 & Epizone \\
\hline RJM917 & BH5 & 128.60 & $\mathrm{~K}$-mica, $\mathrm{Fe} / \mathrm{Mg}$ chlorite & 0.26 & High Anchizone & 0.22 & Epizone \\
\hline RJM918 & $\mathrm{BH} 3$ & 67.66 & K-mica, $((\mathrm{Fe} / \mathrm{Mg}$ chlorite $))$ & 0.43 & Deep Diagenetic & 0.24 & Epizone \\
\hline RJM919 & $\mathrm{BH} 3$ & 99.42 & $\mathrm{~K}$-mica, $\mathrm{Fe} / \mathrm{Mg}$ chlorite & 0.26 & High Anchizone & 0.24 & Epizone \\
\hline RJM920 & $\mathrm{BH} 3$ & 75.42 & K-mica, Fe-rich chlorite & 0.28 & High Anchizone & 0.23 & Epizone \\
\hline RJM921 & $\mathrm{BH} 2$ & 107.19 & K-mica, Fe-rich chlorite & 0.42 & Deep Diagenetic & 0.24 & Epizone \\
\hline RJM922 & $\mathrm{BH} 2$ & 106.10 & K-mica, Fe-rich chlorite & 0.43 & Deep Diagenetic & 0.25 & Epizone \\
\hline RJM923 & $\mathrm{BH} 2$ & 48.00 & $\mathrm{~K}$-mica, (Fe-rich chlorite) & 0.50 & Deep Diagenetic & 0.29 & Anchizone \\
\hline RJM924 & BH4B & 108.20 & K-mica, Fe-rich chlorite & 0.48 & Deep Diagenetic & 0.26 & Anchizone \\
\hline RJM925 & BH4B & 66.35 & K-mica, Fe-rich chlorite & 0.39 & Low Anchizone & 0.28 & Anchizone \\
\hline RJM926 & BH6 & 55.60 & K-mica, Fe-rich chlorite & 0.33 & Low Anchizone & 0.25 & Epizone \\
\hline
\end{tabular}

() - minor component, (()) - trace component.

Samples from the overlying Windermere Supergroup, including a single Ashgill/Llandovery sample, in the Horton boreholes are also composed of quartz, $2 M_{1}$ muscovite, $1 M_{I b b}$ ferroan clinochlore and albite with calcite, dolomite and pyrite also typically present.

\section{4.a. Less than $2 \mu \mathrm{m}$ clay mineral assemblages}

Less than $2 \mu \mathrm{m}$ fractions for all the studied samples are dominated by K-mica with varying amounts of chlorite and subordinate quartz and albite. No Na-mica or pyrophyllite were detected in the assemblages (Tables 3, 4).

Low values $(<0.25)$ for the chlorite peak intensity ratio $\left(d_{001}: d_{002}\right)$ for the outcrop and borehole Ingleton Group samples, including the metabasalt dyke and the Ashgill/Llandovery sample, are indicative of an Ferich chlorite composition. In contrast, the chlorite in the overlying Windermere Supergroup is characterized by having higher values $(>0.25)$ for the same peak intensity ratio, indicating that these chlorites have a more Mg-rich chemistry.

\section{4.b. Illite and chlorite crystallinity}

Samples collected from the Ingleton Group in the Horton boreholes are generally at deep diagenetic grade $\left(\mathrm{KI}=0.39-0.5\right.$, mean $0.44 \Delta^{\circ} 2 \theta$, Fig. 2$)$ with only a single low anchizonal value $\left(0.39 \Delta^{\circ} 2 \theta\right)$ (Table 3$)$.

In contrast, Ingleton Group samples from outcrops at Ingleton are generally at higher grades (Table 4). Along the River Twiss, samples (RJM731, MPA22422265) show consistent low anchizonal values $(\mathrm{KI}=$ $0.33-0.38$, mean $0.36 \Delta^{\circ} 2 \theta$ ). Samples from outcrops exposed along the River Doe, Ingleton, show low anchizonal values $\left(\mathrm{KI}=0.31-0.38\right.$, mean $\left.0.34 \Delta^{\circ} 2 \theta\right)$ 
Table 4. Clay mineralogy, Kübler indices, chlorite crystallinities and metapelitic zones for the Ingleton outcrop samples

\begin{tabular}{|c|c|c|c|c|c|c|}
\hline Sample no. & Location (Ingleton) & $<2 \mu$ m clay mineralogy & $\begin{array}{l}\text { Kübler Index } \\
\left(\mathrm{KI}, \Delta^{\circ} 2 \theta\right)\end{array}$ & $\begin{array}{c}\text { Metapelite Zone } \\
(\mathrm{KI})\end{array}$ & $\begin{array}{c}\text { Chlorite } \\
\text { crystallinity } \\
\left(\mathrm{ChC}_{002}, \Delta^{\circ} 2 \theta\right)\end{array}$ & $\begin{array}{c}\text { Metapelite } \\
\text { Zone } \\
\left(\mathrm{ChC}_{002}\right)\end{array}$ \\
\hline RJM730 & Road cutting at quarry entrance & K-mica, Fe-rich chlorite & 0.37 & Low Anchizone & 0.25 & Epizone \\
\hline RJM731 & Pecca Falls, River Twiss & K-mica, Fe-rich chlorite & 0.35 & Low Anchizone & 0.24 & Epizone \\
\hline RJM927 & Old slate quarry, River Doe & K-mica, Fe-rich chlorite & 0.22 & Epizone & 0.19 & Epizone \\
\hline RJM929 & Old slate quarry, River Doe & K-mica, Fe-rich chlorite & 0.31 & Low Anchizone & 0.24 & Epizone \\
\hline RJM1070 & Old slate quarry, River Doe & K-mica, Fe-rich chlorite & 0.34 & Low Anchizone & 0.24 & Epizone \\
\hline RJM1071 & Below Snow Falls, River Doe & K-mica, Fe-rich chlorite & 0.38 & Low Anchizone & 0.27 & Anchizone \\
\hline RJM1073 & Old slate quarry, River Doe & K-mica, Fe-rich chlorite & 0.39 & Low Anchizone & 0.25 & Epizone \\
\hline RJM1076 & Below Beezley Falls, River Doe & K-mica, Fe-rich chlorite & 0.35 & Low Anchizone & 0.24 & Epizone \\
\hline RJM1077 & Quarry, B6255 & K-mica, Fe-rich chlorite & 0.35 & Low Anchizone & 0.29 & Anchizone \\
\hline MPA2242 & Above Thornton Force, River Twiss & K-mica, Fe-rich chlorite & 0.38 & Low Anchizone & 0.27 & Anchizone \\
\hline MPA2243 & Above Thornton Force, River Twiss & K-mica, Fe-rich chlorite & 0.38 & Low Anchizone & 0.26 & Anchizone \\
\hline MPA2245 & Above Thornton Force, River Twiss & K-mica, Fe-rich chlorite & 0.38 & Low Anchizone & 0.27 & Anchizone \\
\hline MPA2260 & Footpath, Pecca Falls, River Twiss & K-mica, Fe-rich chlorite & 0.36 & Low Anchizone & 0.25 & Epizone \\
\hline MPA2262 & Footpath, Pecca Falls, River Twiss & K-mica, Fe-rich chlorite & 0.33 & Low Anchizone & 0.24 & Epizone \\
\hline MPA2263 & Pecca Falls footbridge, River Twiss & K-mica, Fe-rich chlorite & 0.33 & Low Anchizone & 0.23 & Epizone \\
\hline MPA2265 & Pecca Quarry, River Twiss & K-mica, Fe-rich chlorite & 0.38 & Low Anchizone & 0.26 & Anchizone \\
\hline MPA2275 & Above Snow Falls, River Doe & K-mica, Fe-rich chlorite & 0.34 & Low Anchizone & 0.25 & Epizone \\
\hline MPA2279 & Above Snow Falls, River Doe & K-mica, Fe-rich chlorite & 0.38 & Low Anchizone & 0.24 & Epizone \\
\hline MPA2281 & Lower Baxengill Gorge, River Doe & K-mica, Fe-rich chlorite & 0.22 & Epizone & 0.17 & Epizone \\
\hline MPA2284 & Below Beezley Falls, River Doe & K-mica, Fe-rich chlorite & 0.25 & High Anchizone & 0.18 & Epizone \\
\hline MPA2285 & Below Beezley Falls, River Doe & K-mica, Fe-rich chlorite & 0.25 & High Anchizone & 0.20 & Epizone \\
\hline MPA2290 & Above Beezley Falls, River Doe & K-mica, Fe-rich chlorite & 0.32 & Low Anchizone & 0.23 & Epizone \\
\hline
\end{tabular}

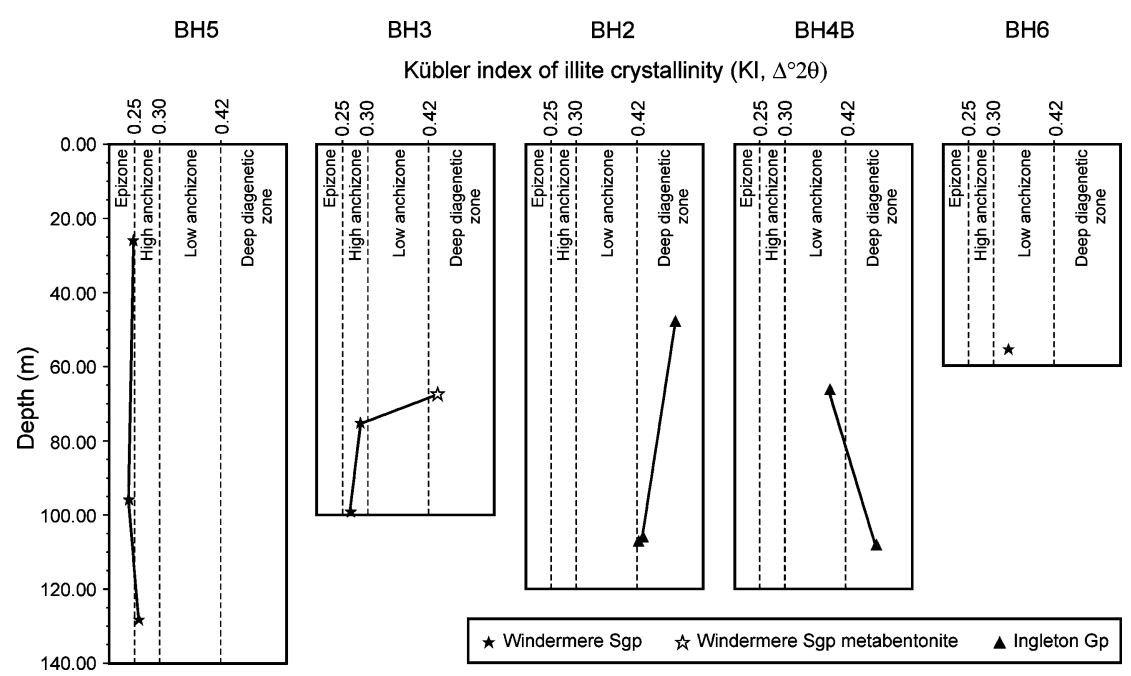

Figure 2. Illite crystallinity downhole plots for the Horton Quarry borehole samples, Horton-in-Ribblesdale.

in the Snow Falls area and the most northerly sample above Beezley Falls (RJM929, MPA2275, MPA2279 and MPA2290), while samples from the central section around Baxengill Gorge and below Beezley Falls (MPA2281-2285) are of high anchizonal or epizonal grade $\left(\mathrm{KI}=0.22-0.25\right.$, mean $0.24 \Delta^{\circ} 2 \theta$ ). Samples from quarries to the south (RJM927, RJM1070) and east of the River Doe (RJM730) show epizonal (KI = $0.22 \Delta^{\circ} 2 \theta$ ) and low anchizone (KIs $=0.34$ and 0.37 $\Delta^{\circ} 2 \theta$ ) values, respectively.

Windermere Supergroup samples from the Horton boreholes are generally at epizonal to high anchizonal grades $\left(\mathrm{KI}=0.24-0.28\right.$, mean $0.26 \Delta^{\circ} 2 \theta$, RJM915, 916, 917, 919 and 920, Fig. 2). A single sample (RJM926) from the oldest Windermere Supergroup (Ashgill/Llandovery) strata in Horton BH6 produced a low anchizonal KI of $0.33 \Delta^{\circ} 2 \theta$. The anomalous deep diagenetic value of $0.43 \Delta^{\circ} 2 \theta$ obtained from the metabentonite (RJM918) is not unusual for this type of volcanogenic mudrock. Bentonites commonly show evidence of retarded reaction progress relative to their mudstone/shale host (see Merriman \& Peacor, 1999, pp. 52-3).

For each of the samples analysed, $\mathrm{ChC}_{002}$ produced a smaller value than $\mathrm{ChC}_{001}$, but both indices generally predict similar metamorphic grades.

All the Windermere Supergroup samples from the Horton boreholes, including the metabentonite, present $\mathrm{ChC}_{002}$ widths typical of the epizone. Chlorite in the Ingleton Group samples from the same boreholes suggests either epizonal (RJM921, 922) or anchizonal (RJM923-925) metamorphism. A similar spread of grades is indicated by the Ingleton Group outcrop samples (epizonal, RJM730, 731, 926, 927, 929, 1073, 


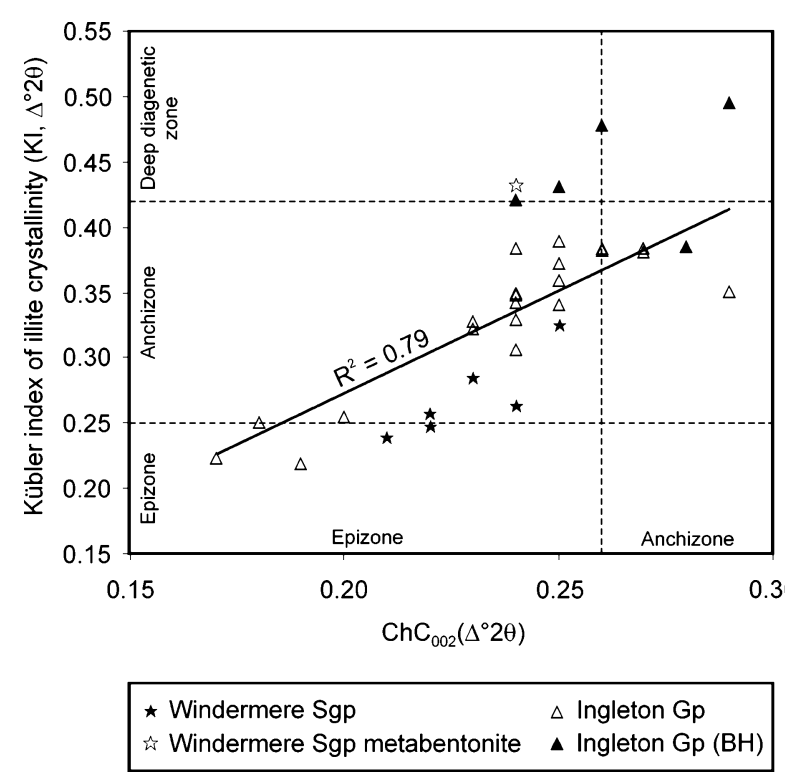

Figure 3. Illite crystallinity (IC) versus chlorite crystallinity (ChC) cross-plot.

1076, MPA2260, 2262, 2263, 2275-2285, 2290, and anchizonal, MPA2242-2245, 2265, RJM1071, 1077). In all cases, $\mathrm{ChC}_{001}$ and $\mathrm{ChC}_{002}$ suggest a similar or greater degree of crystallinity and therefore more advanced metamorphic grade than KI.

A cross-plot of $\mathrm{ChC}_{002}$ versus KI (Fig. 3) indicates a positive correlation between the two indices $\left(\mathrm{R}^{2}=\right.$ 0.79 ) for the Ingleton Group outcrop samples. The Windermere Supergroup samples show an approximately similar trend. However, the Ingleton Group samples from the boreholes and the metabentonite plot separately.

\section{4.c. K-white mica $b$ cell dimensions}

$\mathrm{K}$-white mica $b$ cell dimensions for the Ingleton Group samples from the Horton boreholes range from 9.012$9.018 \AA$ (mean $9.016 \AA$ ), while those for outcrops in the Ingleton Inlier show a similar range of $b$ values (8.989-9.035, mean 9.005 $\AA$ ) (Tables 1, 2).
Larger $b$ cell dimensions are typical of the overlying Windermere Supergroup in the Horton boreholes and range from 9.022-9.034 $\AA$ (mean 9.027 $\AA$ ). The single sample from the oldest Windermere Supergroup (Ashgill/Llandovery) strata in Horton BH6 produced a similarly large $b$ cell dimension of $9.017 \AA$ (Table 1).

A cross-plot of $b$ cell dimensions versus K-white mica $d_{001}$ spacing shows a reasonable correlation (Fig. 4). When compared with the Ingletonian samples, the larger $b$ cell dimensions for the Windermere Supergroup samples are paired with smaller $d_{001}$ spacings.

\section{Petrography}

Thin-section petrographical studies were made of selected samples of the Ingleton Group, and minor intrusions cutting these strata, in order to characterize the degree of alteration and fabric development.

Pelites from the Ingleton Group typically consist of alternations of mudstone and fine-grained sandstone laminae up to $15 \mathrm{~mm}$ in thickness. The mudstone comprises silt-size grains of quartz, muscovite and chlorite-mica stacks in a matrix of clay minerals which are aligned in an anastomosing spaced fabric. This fabric is essentially bedding-parallel but shows variable degrees of development. Close to boundaries with sandstone interbeds, it may be an intense schistosity, but in other parts of the mudstone it is well spaced. Sandstone interbeds have two sets of white-mica filled veins at approximately $45^{\circ}$ to each other, and the bedding. These veins are cut by chlorite-filled veins that are oblique $\left(15-25^{\circ}\right)$ to the bedding lamination (Fig. 5a). Within these veins chlorite is not foliated, and in places flakes appear to have grown normal to the vein walls.

Hornfelsed pelitic rocks at depths of $\sim 267-$ $527 \mathrm{~m}$ in Beckermonds Scar Borehole show many similarities with the Ingleton Group rocks in the Horton boreholes. They are spotted hornfelses consisting of interbedded mudstone and sandstone laminae cut by

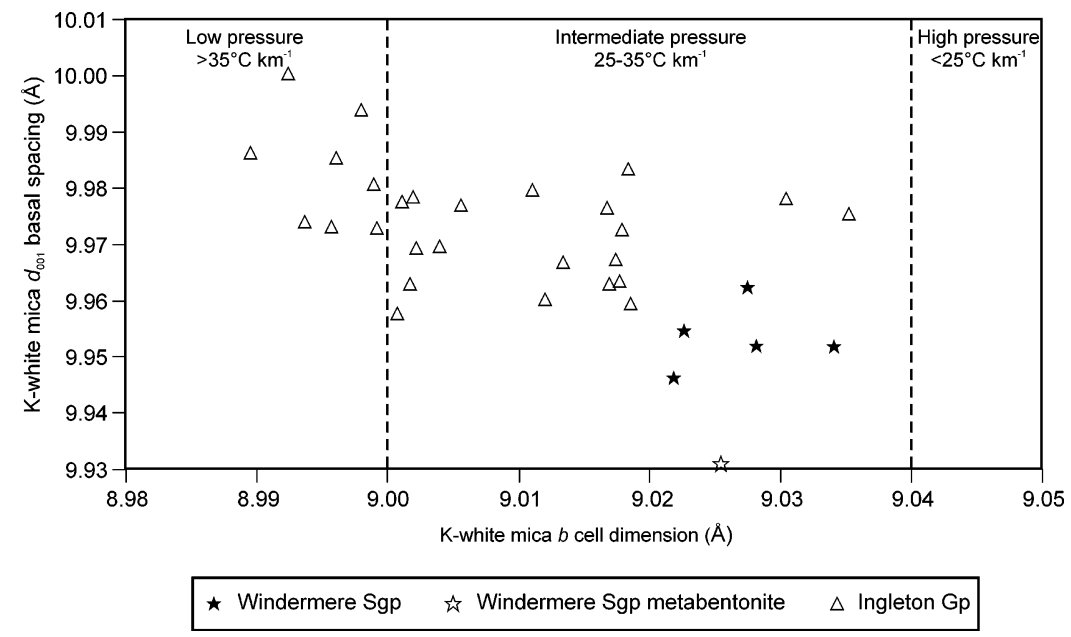

Figure 4 . K-white mica $b$ cell dimensions versus $d_{001}$ spacing cross-plot. 

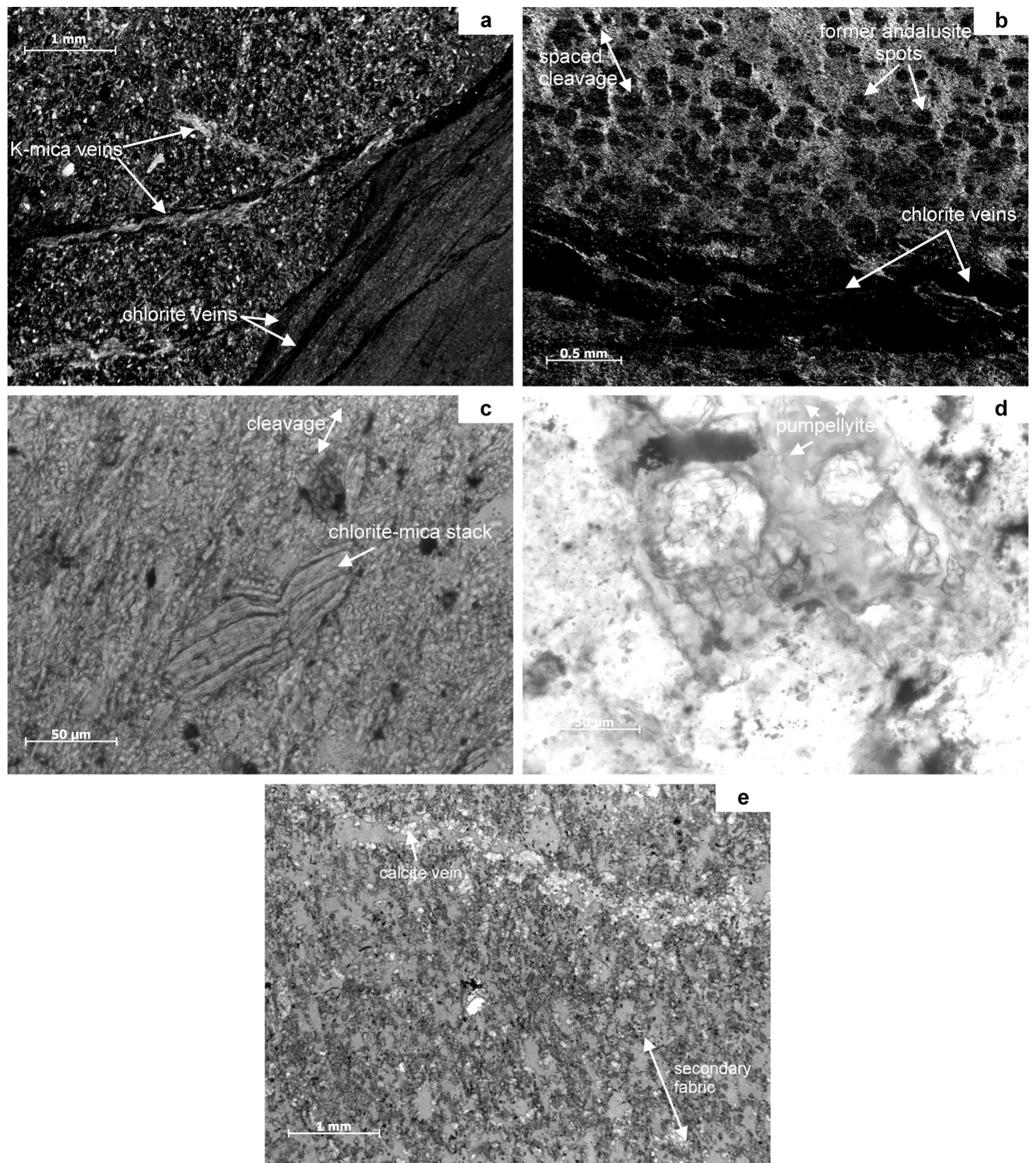

Figure 5. Petrographical features of the typical Ingleton Group lithologies. (a) Pelite with alternating sandstone and mudstone laminae. Note the schistose bedding-parallel fabric of the mudstone close to the sandstone interface and the two sets of white-mica filled veins at approximately $45^{\circ}$ to each other and the bedding. Later chlorite-filled veins are oblique $\left(15-25^{\circ}\right)$ to the bedding, sample RJM922, Horton BH2, $106.10 \mathrm{~m}$. (b) Spotted hornfels consisting of interbedded mudstone and sandstone laminae cut by bedding-subparallel chlorite-filled veins. The elongated spots were originally andalusite but now consist of chlorite and white mica and appear to be orientated along the lamination. Note, however, the lack of bedding-parallel fabric shown in (a). A discontinuous spaced cleavage is oblique to the bedding lamination and has been recrystallized and overprinted by the andalusite microporphyroblasts, sample E54332, Beckermonds Scar Borehole, $399.48 \mathrm{~m}$. (c) Slate showing a single penetrative slaty cleavage which is parallel to the silty laminae of the original mud. Chlorite-mica stacks are common in the silty bands and usually have their stacking planes sub-parallel to the cleavage, sample E37128, Pecca Falls, River Twiss. (d) Greywacke sandstone showing replacement of plagioclase grains by pumpellyite, sample RJM1078, old Ingleton 'Granite' quarry, B6255. (e) Porphyritic metabasalt dyke composed of plagioclase microphenocrysts in a fine-grained groundmass that is now composed of albite, chlorite, quartz, opaque Fe-oxide and patchy carbonate. A crude secondary fabric is evident from the alignment of chlorite-rich domains arranged in a series of discontinuous seams and elongated areas of patchy replacement in the groundmass. The chloritic fabric is cut by calcite-filled veins, sample RJM1072, old slate quarry, River Doe. 
chlorite-filled veins. Elongated spots $(<0.8 \mathrm{~mm}$ long $)$ are concentrated in the mudstone laminae and were originally andalusite but now consist of chlorite and white mica. The spots appear to be orientated along the lamination but, unlike the Ingleton Group pelites in the Horton boreholes, bedding-parallel fabric in the mudstone bands is weak or absent. A discontinuous spaced cleavage is oblique to the bedding lamination and has been recrystallized and overprinted by the andalusite microporphyroblasts. Late veins of chlorite, commonly subparallel with bedding, have also been thermally altered with much opaque Fe-oxide replacing the chlorite (Fig. 5b).

\section{5.a. Ingleton Group slates}

Petrographical characterization of typical slates from the Ingleton Group was made using a standard thinsection $(<30 \mu \mathrm{m}$ thick $)$ and an ultra-thin-section $(<15 \mu \mathrm{m}$ thick). The ultra-thin-section of a slate from the Old Ingleton 'Granite' Quarry (RJM 1077) shows a single penetrative slaty cleavage consisting of anastamosing domains of white mica and chlorite, $4-16 \mu \mathrm{m}$ thick and typically $80 \mu \mathrm{m}$ long. These aligned phyllosilicate domains enclose grains of quartz $(<40 \mu \mathrm{m})$ and less commonly chlorite-mica stacks $(<30 \mu \mathrm{m})$. The latter are predominantly composed of chlorite with thin lamellae of white mica indicating the (001) stacking planes, which in most grains are subparallel to the slaty cleavage. The standard thin-section of slate from the old quarry at Pecca Falls (E37128) also shows a single penetrative slaty cleavage which is parallel to silty laminae in the original mud. Chloritemica stacks are common in the silty bands and usually have their stacking planes sub-parallel to the cleavage (Fig. 5c).

\section{5.b. Ingleton Group greywackes}

Several thin-sections of greywacke from the Old Ingleton 'Granite' Quarry were examined (E17992, E38791, RJM1078). They show that the greywacke is a heterolithic coarse sandstone with individual grains up to $5 \mathrm{~mm}$ across contained in a matrix of white mica and chlorite. Quartz grains are dominant and include unstrained volcanic types, strained and sutured polycrystalline types and quartzite clasts. Angular plagioclase grains are common: some are unaltered lamellar twinned clasts, other are internally resorbed volcanic phenocrysts or are sericitized. Clasts of volcanic rock, including mafic and felsic lava, are also common. Muscovite schist, muscovite flakes and chlorite-mica stacks are also present in minor amounts, with zircon, titanite and epidote present as accessory minerals. Some plagioclase grains are partially or completely replaced by pumpellyite (Fig. $5 \mathrm{~d}$ ), although optical identification has not been verified by electron microprobe analysis.

\section{5.c. Minor intrusions}

Samples of the dyke exposed in the old slate workings [SD 7034 7443] and the two thinner dykes $(<0.5 \mathrm{~m})$ that cross the gorge of the River Doe [SD 7043 7435] were examined in thin-section. They are porphyritic basalts composed of plagioclase microphenocrysts, up to $3 \mathrm{~mm}$ long, in a fine-grained $(<0.05 \mathrm{~mm})$ groundmass that is now composed of albite, chlorite, quartz, opaque Fe-oxide and patchy carbonate. The plagioclase is completely replaced, mainly by albite, quartz and chlorite, and less commonly calcite. In the margins of the dykes (RJM 998, 1074, 1075), the long axes of the microphenocrysts are commonly in sub-parallel alignment, whereas no mineral alignment is apparent in the groundmass. This is probably a primary igneous fabric caused by cooling and viscosity contrasts across the sheet during magma emplacement. The dyke margins of the quarry exposure appear to contain scattered vesicles $(<2 \mathrm{~mm})$ filled with sub-radial chlorite or calcite. Although all the samples are pervasively altered, and are now lowgrade metabasalts, none of them contain diagnostic mineral assemblages that are indicative of metamorphic grade. A crude secondary fabric is present in all the dyke samples, generated by the alignment of chloriterich domains arranged in a series of discontinuous seams and elongated areas of patchy replacement in the groundmass. Within this fabric, chlorite flakes may show a local foliation, but elsewhere the chlorite may be subradial or random. A consistent penetrative schistosity is not developed. In one sample, from the quarry intrusion, the chloritic fabric is cut by calcitefilled veins, up to $0.7 \mathrm{~mm}$ wide (Fig. 5e).

\section{Burial and metamorphic history}

This study provides several lines of evidence suggesting that the Ingleton Group has a polymetamorphic history. The most compelling evidence is the existence of a metamorphic inversion across the unconformity between the Ingleton Group and the overlying Windermere Supergroup, where higher-grade strata rest on lower-grade strata. This was found in the series of boreholes drilled in Horton Quarry that penetrated the 'double unconformity' between the Carboniferous Limestone and Windermere Supergroup, and the Windermere Supergroup and Ingleton Group. Below the older unconformity the Ingleton Group rocks are generally at deep diagenetic grade with one low anchizonal value (Fig. 2). Above the unconformity, KI values in the Windermere Supergroup indicate epizonal to high anchizonal grades. While the clay mineral assemblages are similar, both being dominated by $2 M_{1}$ muscovite with varying amounts of $1 M_{I b b}$ ferroan clinochlore, the chlorite is more $\mathrm{Mg}$-rich in the Windermere Supergroup compared with Fe-rich chlorite of the Ingleton Group. However, chlorite 'crystallinity' $\left(\mathrm{ChC}_{002}\right)$ does not agree with the 
metapelitic grades indicated by KI values in the Ingleton Group. Chlorite 'crystallinity' for the Ingleton Group from the Horton boreholes suggests more advanced epizonal or anchizonal grades and plots off the 'normal' $\mathrm{ChC}_{002}$ v. KI trend (Fig. 3). This possibly reflects the presence of detrital chlorite-mica stacks and also well-crystallized chlorite filling veins in the Ingletonian rocks. In contrast, chlorite 'crystallinity' $\left(\mathrm{ChC}_{002}\right)$ in the Windermere Supergroup indicates epizonal grades, in broad agreement with KI values.

Within the Ingletonian rocks there are differences in grade between the Ingleton and Horton inliers, as noted by Dodson \& Robinson (2006). While the KIs indicate mainly deep diagenetic grades in the Horton borehole samples, outcrop mudrocks from Ingleton are typically low anchizone but a few samples are high anchizone or epizone (Table 4). Outcrop samples of greywacke contain suspected secondary pumpellyite (Fig. 5d), which suggests that prehnite-pumpellyitefacies metamorphism affected these rocks. These local variations in grade indicate different levels of exhumation of the Ingleton Group prior to deposition of the Windermere Supergroup, discussed below. There is no field evidence that the metamorphic inversion is the result of thrust tectonics superimposing high-grade onto low-grade rocks. Instead, the evidence suggests that repeated episodes of regional compression, uplift and erosion have superimposed two metamorphic events, and the later one only partially overprinted the earlier one.

A third local metamorphic event is recorded in the Ingleton Group rocks found in Beckermonds Scar Borehole. These rocks have been contact metamorphosed in the aureole of the concealed Wensleydale granite (Wilson \& Cornwell, 1982; Berridge, 1982). Lithologically they closely resemble the Ingletonian rocks found in the Horton boreholes, consisting of laminated mudstone with thin sandstone bands cut by chlorite-filled veins, the latter possibly sealed hydrofractures (Fig. 5b). A spaced cleavage oblique to bedding lamination has been overprinted by andalusite spots and the veins are thermally altered to opaque Fe-oxide replacing much of the chlorite. It is clear that the cleavage and veining in these Ingletonian hornfelses pre-dates the late Ordovician intrusion of the Wensleydale granite at $442 \pm 3 \mathrm{Ma}$ (Noble, Tucker \& Pharaoh, 1993).

Further evidence of a polyphase metamorphic history is found in the K-white mica $b$ cell dimensions. The generally smaller $b$ dimensions derived from the Ingletonian sample suite (mean 9.007 A, Fig. 6) are indicative of development at low to intermediate pressures, suggesting geothermal gradients during burial no lower than $25^{\circ} \mathrm{C} \mathrm{km}^{-1}$ and possibly much higher than $35^{\circ} \mathrm{C} \mathrm{km}^{-1}$ (Guidotti \& Sassi, 1986). The $b$ cell dimensions obtained from the Windermere Supergroup rocks in the Horton boreholes are generally larger (mean 9.027 $\AA$, Fig. 6) than those from the Ingletonian, and are indicative of development at intermediate pressures and burial under geothermal

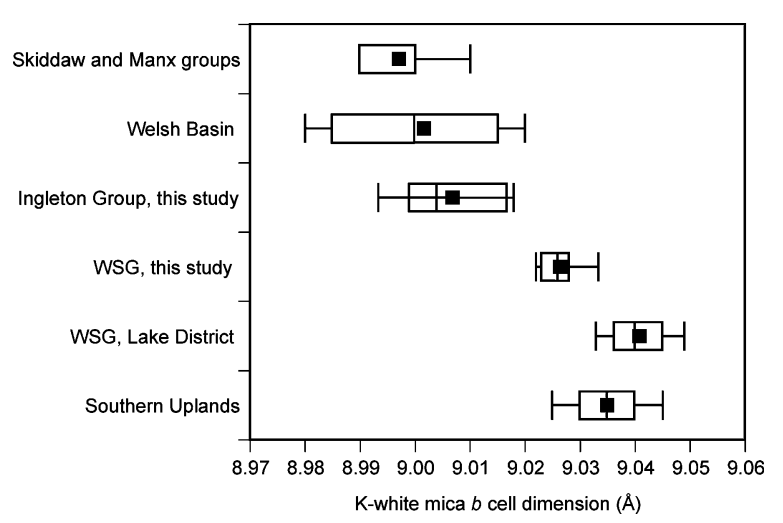

Figure 6. Boxplot to compare the $\mathrm{K}$-white mica $b$ cell dimension distributions of the Ingleton Group and Windermere Supergroup from Horton with pelites from the Southern Uplands of Scotland, the Welsh Basin, the Windermere Supergroup from the Lake District and the Skiddaw and Manx Groups (from Stone \& Merriman, 2004). For each dataset, the box points represent the 10th, 25th, median, 75th and 90th percentile respectively. The mean value is represented by a black filled square.

gradients that did not exceed $35^{\circ} \mathrm{C} \mathrm{km}^{-1}$ (Guidotti \& Sassi, 1986).

Contrasts in $b$ cell dimension data, similar to those found at Horton, are a characteristic of the different Lower Palaeozoic basins found in the British Caledonides (Stone \& Merriman, 2004). Published $b$ dimension data for various basins are summarized in Figure 6, and fall into two groups. Mudrock samples from the Southern Uplands, Scotland and the Windermere Supergroup, southern Lake District, possess the largest $b$ dimensions, with mean values of $9.034 \AA$ and $9.041 \AA$, respectively. Such a range of values indicates intermediate- to high-pressure facies series and low geothermal gradients (Fig. 6), and are associated with convergent plate tectonic settings in the British Caledonides (Merriman, 2002). A second group comprises the Welsh Basin and the Skiddaw and Manx groups showing smaller $b$ dimensions with mean values of $9.001 \AA$ and $8.997 \AA$ respectively (Fig. 6). These $\mathrm{K}$-white micas were generated in extensional basins with higher geothermal gradients but corresponding to the low-pressure facies series (Fig. 6). The $b$ dimensions derived from this study plot in one or other of two regional groups identified in Figure 6. Those from the Ingleton Group generally correspond with the extensional basin setting of the Welsh Basin and Skiddaw and Manx groups, whereas $b$ dimension data from the Windermere Supergroup in Horton boreholes fall in the range of the convergent basin setting of the Southern Uplands and the Lake District Windermere Supergroup (Fig. 6).

Differences in $b$ dimension populations and the contrasts in metamorphic grade noted above indicate that two low-grade regional metamorphic events have affected the Ingleton Group in the Craven inliers. An earlier event is characterized by a relatively high geothermal gradient and probably represents deep burial in an extensional basin setting. A later event, 
a

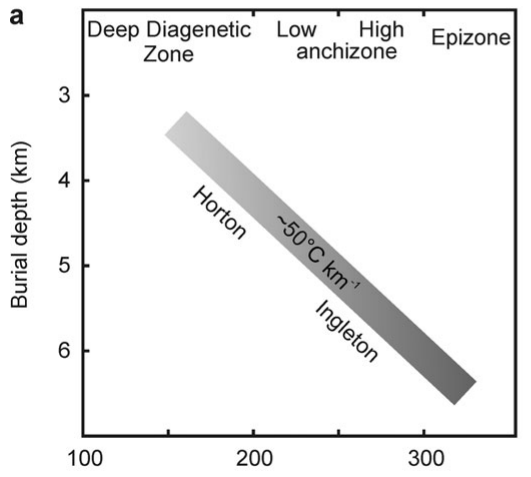

b

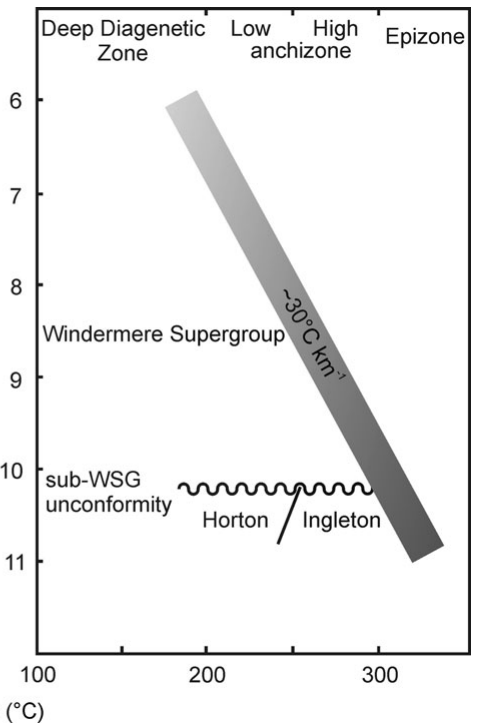

Figure 7. Metamorphic history models for the Craven inliers assuming: (a) a field gradient of $50{ }^{\circ} \mathrm{C} \mathrm{km}^{-1}$ (derived from the Welsh Basin); (b) a field gradient of $30^{\circ} \mathrm{C} \mathrm{km}^{-1}$ and at least two fault blocks in the Craven inliers.

characterized by a relatively low geothermal gradient, took place in a convergent basin setting and was associated with tectonic deformation. Despite the slaty cleavage development resulting from the second metamorphic event (Soper \& Dunning, 2005), the effects of tectonic overprinting on clay mineral assemblages generated by the first event in the Ingletonian mudrocks appear to be minimal. We attempt to explain the lack of metamorphic overprinting on clay minerals in the metamorphic history below.

A model of the metamorphic history of the Craven inliers is summarized in Figure 7. Based on their $b$ cell dimensions, we assume the $\mathrm{K}$-white mica in the Ingleton Group was generated in an extensional basin setting, perhaps similar to that of the Welsh Basin. Palaeogeothermal (field) gradients generated during the burial metamorphism and subsequent Acadian deformation of the Welsh Basin ranged from 37 to $52{ }^{\circ} \mathrm{C} \mathrm{km}^{-1}$ (Bevins \& Merriman, 1988; Bottrell et al. 1990). In Figure $7 \mathrm{a}$ we have modelled the earlier Ingletonian metamorphism using the higher end of the range of field gradients derived from the Welsh Basin; a lower gradient would have the effect of increasing the inferred depth of burial. A field gradient of $50{ }^{\circ} \mathrm{C} \mathrm{km}^{-1}$ indicates that the Ingletonian metamorphic event was the result of burial to approximately $5 \mathrm{~km}$ for the outcrop at Ingleton and around $4 \mathrm{~km}$ for Horton, where grade is lower. At Ingleton, pumpellyite appears to replace plagioclase grains in some feldspathic greywackes, suggesting that prehnite-pumpellyite-facies conditions were reached during burial, implying temperatures of $200-300^{\circ} \mathrm{C}$ and pressures in excess of $1.5 \mathrm{kbar}$ (Schiffman \& Day, 1999). There is no evidence that a penetrative tectonic fabric was developed in mudrocks during this early event (Soper \& Dunning, 2005). A beddingparallel fabric reported by Soper \& Dunning (2005) from Ingleton is also present in the Ingleton Group mudstones in the Horton boreholes. A similar beddingparallel fabric has been reported from mudstones in the Skiddaw Group and is attributed to burial under a high geothermal gradient (Stone, Cooper \& Evans, 1999; Cooper et al. 2004). However, the origin of the spaced cleavage overprinted by contact metamorphism in the Ingletonian mudstones in Beckermonds Scar Borehole is unclear. The $\mathrm{Rb}-\mathrm{Sr}$ whole-rock isochron age of $465 \pm 10$ Ma obtained by Dodson \& Robinson (2006) suggests that this first metamorphic event took place in the Lower Ordovician (Arenig).

Exhumation of the metamorphosed Ingleton Group must have occurred before the late Ordovician, prior to deposition of strata of Ashgill age. The difference in level of uplift between Ingleton and Horton, approximately $1 \mathrm{~km}$ over a horizontal distance of less than $10 \mathrm{~km}$ (Fig. 7a), suggests that the Ingleton Group comprises at least two fault blocks in the Craven inliers (Fig. 7b). The blocks and intervening fault(s) were probably initiated during uplift of the metamorphosed Ingleton Group, and possibly reactivated during the subsidence of the basement that accommodated deposition of the Windermere Supergroup. The large isoclinal fold pair, the Skirwith Syncline in the Ingleton Inlier and Horton Anticline, may have developed as a result of differential block movement in the subIngletonian basement at this time.

Three independent lines of evidence suggest that the basaltic dykes were intruded after the early deformation of the Ingleton Group, but prior to the second Acadian deformation.

Firstly, the dykes are sub-vertical sheets up to $1 \mathrm{~m}$ wide, emplaced in steeply dipping strata. If the dykes had been emplaced as typical cross-cutting intrusions prior to deformation, they would be unlikely to show this degree of parallelism with bedding. On the other hand, if the intrusions were originally bedding-concordant sills, then the folding necessary 
to bring them to their present attitude would be expected to involve shortening and/or extension, and fracturing of the competent igneous sheets within the less competent sediments. Hence a much greater degree of deformation and cleavage development would be expected than is apparent in the field if the dykes were pre-deformation.

Secondly, the petrography does not provide any evidence of secondary pumpellyite in the dykes, in contrast to its occurrence in the Ingletonian greywackes. Moreover, the petrography does not support the development of an internal penetrative fabric. Some dyke samples show a primary igneous alignment of plagioclase microphenocrysts, and most samples have a crude foliation defined by discontinuous veins and seams of chlorite that are sub-parallel with the sheet margins. However, a penetrative secondary fabric is not developed, but would be expected if these rocks had been deformed when the host sediments were deformed.

Thirdly, the Fe-rich composition of the chlorite in the dykes more closely resembles that developed in the Ingleton Group rather than the more Mg-rich species developed in the Windermere Supergroup. In each case, the chlorite compositions are likely to be primarily controlled by bulk-rock chemistry (Zane, Sassi \& Guidotti, 1998).

Together these lines of evidence suggest that the basaltic dykes were emplaced during or shortly after exhumation, and after the folding of the Ingleton Group.

During late Ordovician and through Silurian times, the Ingleton Group was buried beneath the Windermere Supergroup, with the addition of some $3.5 \mathrm{~km}$ of Lower Old Red Sandstone (Soper \& Woodcock, 2003). The foreland basin setting within which the Windermere Supergroup accumulated (Kneller, King \& Bell, 1993) was characterized initially by low heat flow. However, by Early Devonian times, heat flow had probably increased, and hence the transtensional basin model proposed by Soper \& Woodcock (2003) assumed a field gradient of approximately $35^{\circ} \mathrm{C} \mathrm{km}^{-1}$ at the onset of Acadian deformation. Based on the Kwhite mica $b$ dimension data for the Windermere Supergroup (Figs 4, 6), we have used a gradient of $30^{\circ} \mathrm{C} \mathrm{km}^{-1}$ to model the depth of burial of the Ingleton Group during the deformation and metamorphism resulting from the Acadian event (Fig. 7b). The high anchizone and epizonal grades of the Windermere Supergroup samples in the Horton boreholes suggest that the Ingletonian basement was buried to around $10 \mathrm{~km}$ at the onset of Acadian deformation and metamorphism. Some variation in the depth of burial would have resulted from differential block movement in the basement as reactivated faults accommodated the Windermere Supergroup sedimentation. Further reactivation, particularly reverse faulting would have occurred during Acadian uplift. The Acadian transpression event culminated in the Early Devonian (Emsian), with a local Ribblesdale metabentonite giving a mean
$\mathrm{K}-$ Ar age of $397 \pm 7$ Ma for fabric-forming phengitic mica (Merriman et al. 1995).

The effects of Acadian metamorphic temperatures and fabric formation on Ingletonian clay mineral assemblages vary in the two inliers. In terms of fabric formation, there is good evidence that the Acadian slaty cleavage, well developed in the overlying Windermere Supergroup, was also superimposed on the major fold pair of Ingletonian origin (Soper \& Dunning, 2005). However, while slaty cleavage is strongly developed in the Ingleton Inlier, its development is more variable in the Horton Inlier and also in Beckermonds Scar Borehole. Thus at outcrop, Soper \& Dunning (2005) recorded plentiful evidence of cleavage at Ingleton, whereas the Horton borehole samples of the Ingleton Group rocks carry a fabric that is weak and beddingparallel, although its intensity may be increased at mudstone/sandstone interfaces, suggesting beddingplane slip. This fabric and white mica-filled veins in the sandstones appear to be cut by late chloritefilled veins. The same borehole samples record grades of metamorphism, as indicated by illite 'crystallinity' $(\mathrm{KI})$, lower than those in the overlying cleaved Windermere Supergroup. In terms of both tectonic fabric development and clay crystal growth, these mudstone samples from Horton indicate, at best, only a partial response to the Acadian metamorphic event.

Further examples of metamorphic inversions beneath the Windermere Supergroup have been recorded from two locations in the Lake District.

The Windermere Supergroup strata in the Kendal district (Sheet 39) are typically at low or sometimes high anchizonal grade. However, in the east of the district, these overlie deep diagenetic grade rocks of late Ordovician (Ashgill) age. Although these low grades are associated with the Cautley volcanogenic rocks, a lack of retrogressive mineral phases suggests no significant increase in heat flow occurred when the overlying Windermere Supergroup strata were deformed and metamorphosed by the Acadian event. The presence of calcite may have inhibited the growth of white mica and preserved deep diagenetic grades in the volcanic rocks. Alternatively, the very low grades could result from hydrothermal activity or proximity to the Dent Fault, but these hypotheses lack supporting mineralogical evidence, according to Hirons \& Roberts (1999).

In the Furness Inlier, deep diagenetic to low anchizone Skiddaw Group strata are overlain by Windermere Supergroup strata at middle-anchizonal and epizonal grades (Johnson, Soper \& Burgess, 2001). Although the higher metamorphic grades in the Windermere Supergroup were generated solely by the Acadian event, both the Skiddaw Group and Windermere Supergroup have an Acadian slaty cleavage. The preservation of pre-Acadian burial metamorphic clay mineral assemblages within the Skiddaw Group is ascribed to reaction kinetics, whereby the energy input during the Acadian was insufficient to provide the activation energy required to promote further reactions 
in these more thoroughly dewatered Lower Ordovician rocks.

\section{Discussion}

Evidence for clay minerals generated by an earlier lowtemperature event $\left(<300^{\circ} \mathrm{C}\right)$ being overprinted by a later similar event is not widely recorded. There appears to be more chance of such evidence being preserved where the first event is associated with relatively high heat-flow/low pressure type metamorphism and the second event by low heat-flow/high pressure (Merriman \& Frey, 1999, pp. 104-5). For example, where mudrocks have been bleached and hardened, but not hornfelsed, in low-temperature aureoles (200$300^{\circ} \mathrm{C}$ ) in the Welsh Basin, these rocks have not developed a slaty cleavage in response to the subsequent Acadian deformation and consequently remain at lower grades than the adjacent slates (Merriman \& Roberts, 1985). Loss of water from clay minerals during the first thermal event appears to influence strongly their response to subsequent events, especially if this results in the reduction of smectite interlayers in illite. Cation mobility in fluids evolved during thermal events largely controls reaction progress in white micas, particularly the movement of $\mathrm{K}$ into interlayer sites and the removal of Si from tetrahedral sheets. If the mobility of $\mathrm{K}$ and $\mathrm{Si}$ is inhibited or prevented by previous dehydration, it appears that white mica (illite) cannot develop thicker, more mature crystals in subsequent low temperature events, and this is reflected in the KI measurement. The KI essentially measures the mean thickness of a population of illite crystals in a mudrock sample (Merriman \& Peacor, 1999). At Horton it appears that mean thicknesses of white micas generated by the Ingletonian metamorphic event, indicative of the deep diagenetic zone, were not increased or equilibrated with the high anchizonal to epizonal white micas that were generated by the Acadian event in the overlying Windermere Supergroup. These overlying immature sediments were not thermally altered prior to the Acadian event and probably still contained smectite interlayers in illite.

The different $b$ dimension of K-white micas found in the Ingleton Group and the Windermere Supergroup is further evidence that the early low pressure Ingletonian event was only partially overprinted by the later higher pressure Acadian event. Once again this suggests that white mica equilibration is inhibited where the first event is the result of relatively high heat flow/low pressure and the second event is associated with low heat flow/high pressure. Guidotti, Sassi \& Blencoe (1989) showed that the $b$ cell dimension of K-white mica is affected by two substitutions in the octahedral and tetrahedral sheets:

$$
\begin{gathered}
\left(\mathrm{Mg}, \mathrm{Fe}^{2+}\right)^{\mathrm{VI}}+\mathrm{Si}^{\mathrm{IV}} \leftrightarrow \mathrm{Al}^{\mathrm{VI}}+\mathrm{Al}^{\mathrm{IV}} \\
\left(\mathrm{Fe}^{3+}\right)^{\mathrm{VI}} \leftrightarrow \mathrm{Al}^{\mathrm{VI}}
\end{gathered}
$$

If substitutions are from left to right in these expressions, the $b$ dimension decreases because of the smaller ionic radius of $\mathrm{Al}$ compared with that of $\mathrm{Fe}$ or Mg. Where basinal heat flow is relatively high and pressure is low, the more aluminous micas on the right side of the paired reaction dominate illite populations; where basinal heat flow is low and pressure high (resulting from deep burial), phengitic micas are dominant. However, published studies documenting the effects of thermal overprinting on these substitutions in low-grade metamorphic terranes are few. Offler, McKnight \& Morand (1998) recorded $b$ dimensions of K-white micas generated by overprinting in the aureoles of granites intruded into the accretionary rocks of the Lachlan Fold Belt, Australia. Phengitic $\mathrm{K}$-micas with large $b$ dimensions generated in the low$T$, high- $P$ accretionary complex had been altered to more aluminous micas with lower $b$ dimensions in the aureoles. Similar changes were found by Underwood, Laughland \& Kang (1993) in the accretionary Shimanto Belt, SW Japan. Rapid heating of the Shimanto Belt in the middle Miocene was caused when hot oceanic lithosphere from a spreading ridge entered the subduction zone. Thermal overprinting resulted in K-white mica compositions typical of an intermediate pressure facies series, and $b$ dimensions significantly lower than those of typical phengitic Kwhite micas found in accretionary complexes. Further examples of the lower-pressure overprint of phengitic mica by muscovite mica are recorded from uplifted (decompressed) subduction zones (Dalla Torre et al. 1996; Abad et al. 2003). These examples suggest that where overprinting is caused by an increase in heat flow or reduction in pressure, the $\mathrm{Fe}+\mathrm{Mg}$ (phengite) contents of K-white mica are reduced and the $b$ dimension decreases. In contrast, the study presented here indicates that where aluminous K-white mica was initially generated under high heat-flow conditions, subsequent overprinting under reduced regional heatflow conditions and/or deep burial does not increase the phengite content, that is, does not increase the $b$ cell dimension of $\mathrm{K}$-white mica.

\section{Conclusions}

This study shows that the Ingleton Group has a polyphase history of low-grade metamorphism and deformation spanning some 65-70 Ma of Early Ordovician to Early Devonian time. An early Ingletonian metamorphic event in the Arenig at $465 \pm 10$ Ma was followed by exhumation and probably the intrusion of basaltic dykes. Deformation associated with exhumation may have been responsible for the largescale folds in the Ingleton Group and also the spaced cleavage preserved in the hornfelsed mudstones within the aureole of the concealed Wensleydale granite. The intrusion age of the latter ( $442 \pm 3 \mathrm{Ma})$ suggests that exhumation occurred in late Ordovician times. Subsequent deep burial of the Ingleton Group during Silurian times was followed by a second phase of 
deformation and low-grade metamorphism in the Early Devonian Acadian orogeny at around $397 \pm 7$ Ma.

Although the Acadian slaty cleavage was superimposed on early folds generated during the Ingletonian metamorphism, there was insufficient thermal overprinting to change the composition and, in some cases, the crystal size of white micas. This has resulted in a metamorphic inversion at Horton where grade, as indicated by illite 'crystallinity' (KI), is lower in the Ingleton Group than in the overlying Windermere Supergroup. This study also shows that aluminous Kwhite mica, initially generated under high heat-flow conditions during the Ingletonian metamorphism, did not change to a phengitic white mica with a larger $b$ cell dimension as a result of the subsequent Acadian metamorphism.

While this study throws some light on the metamorphic history of the Ingleton Group, it does not settle the controversy surrounding the age of deposition. The older Neoproterozoic age suggested by Soper \& Dunning (2005), on the basis of $\mathrm{Nd}$ modal ages and clast provenance, and the younger Early Ordovician depositional age based on somewhat tenuous biostratigraphical data, are equally possible in terms of the metamorphic history discussed above. However, there are several strands of evidence that favour an Ordovician age. Firstly, there are wide areas of the northern Lake District and somewhat more restricted areas of the more adjacent southern Lake District with outcrops of Early Ordovician strata, whereas proved Precambrian rocks are absent from this region. Secondly, while provenance studies rule out a shared source for the Skiddaw Group and the Ingleton Group, they do not prevent the two groups of strata from being broadly contemporaneous in terms of depositional age. In this connection it is notable that two Rb-Sr studies, by O'Nions, Hamilton \& Hooker (1983) and Dodson \& Robinson (2006), indicate possible Early Ordovician depositional ages for the Ingleton Group. Finally, two further metamorphic inversions beneath the Windermere Supergroup have been recorded from locations in the Lake District and in both cases the underlying strata belong to the Early Ordovician Skiddaw Group.

Acknowledgements. The authors wish to thank Hanson Aggregates (owners of Horton Quarry) for access to the borehole materials. Jack Soper is also thanked for useful discussions and his enthusiastic support. Stuart Molyneux is acknowledged for suggesting additional analysis of samples from the BGS Palaeontological Collection (MPA sample numbers). This paper, which benefited from constructive internal reviews by Phil Stone and Dave Millward and external reviews by Fernando Nieto and Francesco Perri, is published with the permission of the Executive Director, British Geological Survey (NERC).

\section{References}

AbAD, I., GutiÉrrez-Alonso, G., Nieto, F., Gertner, I., BECKER, A. \& CABERO, A. 2003. The structure and the phyllosilicates (chemistry, crystallinity and texture) of Talas Ala-Tau (Tien Shan, Kyrgyz republic): comparison with more recent subduction complexes. Tectonophysics 365, 103-27.

Arthurton, R. S., Johnson, E. W. \& Mundy, D. C. 1988. Geology of the Country around Settle. Memoir of the British Geological Survey, 1:50,000 Geological Sheet no. 60 (England and Wales). London: HMSO, 156 pp.

ÁRKAI, P. 1991. Chlorite crystallinity: an empirical approach and correlation with illite crystallinity, coal rank and mineral facies as exemplified by Palaeozoic and Mesozoic rocks of northeast Hungary. Journal of Metamorphic Geology 9, 723-34.

BAILEY, S. W. 1987. X-ray diffraction identification of the polytypes of mica, serpentine, and chlorite. Clays and Clay Minerals 36, 193-213.

Berridge, N. G. 1982. Petrography of the Pre-Carboniferous rocks of the Beckermonds Scar borehole in the context of the magnetic anomaly at the site. Proceedings of the Yorkshire Geological Society 44, 89-98.

Bevins, R. E. \& Merriman, R. J. 1988. Co-existing prehnite-actinolite and prehnite-pumpellyite facies assemblages in the Tal y Fan Metabasite Intrusion, North Wales: Implications for Caledonian metamorphism. Journal of Metamorphic Geology 6, 17-39.

Bottrell, S. H., Greenwood, P. B., Yardley, B. W. D., SHEPHERD, T. J. \& SPIRO, B. 1990. Metamorphic and post-metamorphic fluid flow in the low-grade rocks of the Harlech Dome, north Wales. Journal of Metamorphic Geology 8, 131-43.

Cooper, A. H., Fortey, N. J., Hughes, R. A., MolyneuX, S. G., Moore, R. M., Rushton, A. W. A., Stone, P., Allen, P. M., CoOper, D. C., Evans, J. A., Hirons, S. R. \& WEBB, B. C. 2004. The Skiddaw Group of the English Lake District. Memoir of the British Geological Survey. Keyworth, Nottingham: British Geological Survey, $147 \mathrm{pp}$.

Dalla Torre, M., Livi, K. J. T., Veblen, D. R. \& FREY, M. 1996. White K-mica evolution from phengite to muscovite in shales and shale matrix melange. Contributions to Mineralogy and Petrology 123(4), 390405.

Davies, G., Gledhill, A. \& Hawkesworth, C. 1985. Upper crustal recycling in southern Britain: evidence from $\mathrm{Nd}$ and Sr isotopes. Earth and Planetary Science Letters 75, $1-12$.

Dodson, M. H. \& RobINSON, D. 2006. A mid-Ordovician $\mathrm{Rb}-\mathrm{Sr}$ isochron age from the Ingleton Group, North Yorkshire: metamorphism or diagenesis? Proceedings of the Yorkshire Geological Society 56, 81-5.

GrathofF, G. H. \& MoORE, D. M. 1996. Illite polytype quantification using Wildfire calculated X-ray diffraction patterns. Clays and Clay Minerals 44, 835-42.

GuidotTi, C. V. \& SASSI, F. P. 1986. Classification and correlation of metamorphic facies series by means of muscovite b data from low-grade metapelites. Jahrbuch für Mineralogie Abhandlungen 153, 363-80.

Guidotti, C. V., SAssi, F. P. \& Blencoe, J. G. 1989. Compositional controls on the $\mathrm{a}$ and $\mathrm{b}$ cell dimensions of $2 M_{1}$ muscovite. European Journal of Mineralogy $\mathbf{1}$, 71-84.

Hirons, S. R. \& RoBerTs, B. 1999. Metamorphic survey of 1:50 000 Kendal and Kirby Lonsdale geological sheets 39 and 49. British Geological Survey Technical Report WA/99/51.

Hower, J., Eslinger, E. V., Hower, M. E. \& Perry, E. A. 1976. Mechanism of burial metamorphism of argillaceous sediments: Mineralogical and chemical 
evidence. Geological Society of America Bulletin 87, 725-37.

Johnson, E. W., SOPER, N. J. \& Burgess, I. C. 2001. Geology of the country around Ulverston. Memoir for 1:50,000 Geological Sheet 48 (England \& Wales). London: The Stationery Office, for the British Geological Survey, $129 \mathrm{pp}$.

KISCH, H. J. 1991. Illite crystallinity: recommendations on sample preparation, X-ray diffraction settings and interlaboratory standards. Journal of Metamorphic Geology 9, 665-70.

KNeller, B. C., King, L. M. \& Bell, A. M. 1993. Foreland basin development and tectonics on the northwest margin of eastern Avalonia. Geological Magazine 130, 691-7.

Kneller, B. C., Scott, R. W., Soper, N. J., Johnson, E. W. \& ALLEN, P. M. 1994. Lithostratigraphy of the Windermere Supergroup in northern England. Geological Journal 29, 219-40.

LeEDAL, G. P. \& WALKeR, G. P. 1950. A restudy of the Ingletonian Series of Yorkshire. Geological Magazine 87, 57-66.

MERRIMAN, R. J. 2002. Contrasting clay mineral assemblages in British Lower Palaeozoic slate belts: the influence of geotectonic setting. Clay Minerals 37, 207-19.

MERriman, R. J. \& KeMP, S. J. 1996. Clay minerals and sedimentary basin maturity. Mineralogical Society Bulletin 111, 7-8.

Merriman, R. J. \& Frey, M. 1999. Patterns of very lowgrade metamorphism in metapelitic rocks. In LowGrade Metamorphism (eds M. Frey \& D. Robinson), pp. 61-107. Oxford: Blackwell Sciences Ltd.

Merriman, R. J. \& PeAcor, D. R. 1999. Very low-grade metapelites: mineralogy, microfabrics and measuring reaction progress. In Low-grade Metamorphism (eds M. Frey \& D. Robinson), pp. 10-60. Oxford: Blackwell Sciences Ltd.

Merriman, R. J. \& Roberts, B. 1985. A survey of white mica crystallinity and polytypes in mudrocks of Snowdonia and Llŷn, N. Wales. Mineralogical Magazine 49, 305-19.

Merriman, R. J., Rex, D. C., Soper, N. J. \& Peacor, D. R. 1995. The age of Acadian cleavage in northern England, UK: K-Ar and TEM analysis of a Silurian metabentonite. Proceedings of the Yorkshire Geological Society 50, 255-65.

Moore, D. M. \& ReYNOLDS, R. C. 1997. X-Ray Diffraction and the Identification and Analysis of Clay Minerals, Second Edition. New York: Oxford University Press, $378 \mathrm{pp}$.

NixON, P. H., ReX, D. C. \& CondlifFe, E. 1984. A note on the age and petrogenesis of lamprophyre dykes of the Cautley area, Yorkshire Dales National Park. Transactions of the Leeds Geological Association 10(4), 40-5.

Noble, S. R., Tucker, R. D. \& PharaOH, T. C. 1993. Lower Palaeozoic and Precambrian igneous rocks from eastern England and their bearing on Ordovician closure of the Tornquist Sea: constraints from $\mathrm{U}-\mathrm{Pb}$ and $\mathrm{Nd}$ isotopes. Geological Magazine 130, 835-46.

Offler, R., MCKNight, S. \& Morand, V. 1998. Tectonothermal history of the western Lachlan Fold Belt, Australia: insights from white micas. Journal of Metamorphic Geology 16, 531-40.

O’Nions, R. K., OXburgh, E. R., HaWkesworth, C. J. \& MACINTYRE, R. M. 1973. New isotopic and stratigraphical evidence on the age of the Ingletonian. Journal of the Geological Society, London 129, 445-52.
O’Nions, R. K., Hamilton, P. J. \& Hooker, P. J. 1983. A $\mathrm{Nd}$ isotope investigation of sediments related to crustal development in the British Isles. Earth and Planetary Science Letters 63, 229-40.

Padan, A., Kisch, H. J. \& Shagam, R. 1982. Use of the lattice parameter $b_{0}$ of dioctahedral illite/muscovite, for the characterisation of $\mathrm{P} / \mathrm{T}$ gradients of incipient metamorphism. Contributions to Mineralogy and Petrology 79, 85-95.

PEACOR, D. R. 1992. Diagenesis and low-grade metamorphism of shales and slates. In Minerals and Reactions at the Atomic Scale: Transmission Electron Microscopy (ed. P. R. Buseck), pp. 335-80. Mineralogical Society of America, Reviews in Mineralogy no. 27.

PLAYFAIR, J. 1802. Illustrations of the Huttonian Theory of the Earth. Reprinted 1964. New York: Dover Publications, $528 \mathrm{pp}$.

SCHIFFMAN, P. \& DAY, H. W. 1999. Petrological methods for the study of very low-grade metabasites. In Low-Grade Metamorphism (eds M. Frey \& D. Robinson), pp. 108 42. Oxford: Blackwell Sciences Ltd.

SOPER, N. J. \& WoODCOCK, N. H. 2003. The lost Old Red Sandstone of England and Wales: a record of post Iapetan flexure of Early Devonian transtension? Geological Magazine 140, 627-47.

SOPER, N. J. \& DUNNING, F. W. 2005. Structure and sequence of the Ingleton Group, basement to central Pennines of northern England. Proceedings of the Yorkshire Geological Society 55, 241-61.

ŚRODOŃ, J. 1999. Nature of mixed-layer clays and mechanisms of their formation and alteration. Annual Reviews of Earth and Planetary Science 27, 19-53.

Stone, P. \& MERRIMAn, R. J. 2004. Basin thermal history favours an accretionary origin for the Southern Uplands terrane, Scottish Caledonides. Journal of the Geological Society, London 161, 829-36.

Stone, P., CoOper, A. H. \& Evans, J. A. 1999. The Skiddaw Group (English Lake District) reviewed: early Palaeozoic sedimentation and tectonism at the northern margin of Avalonia. In In sight of the suture: the geology of the Isle of Man in its Iapetus Ocean context (eds N. H. Woodcock, W. R. Fitches, D. G. Quirk \& R. P. Barnes), pp. 325-36. Geological Society of London, Special Publication no. 160.

Underwood, M. B., Laughland, M. M. \& Kang, S. M. 1993. A comparison among organic and inorganic indicators of diagenesis and low-temperature metamorphism, Tertiary Shimanto Belt, Shikoku, Japan. In Thermal evolution of the Tertiary Shimanto Belt, Southwest Japan: An example of ridge-trench interaction (ed. M. B. Underwood), pp. 45-61. Geological Society of America, Special Paper no. 273.

WARR, L. \& RICE, A. H. N. 1994. Interlaboratory standardization and calibration of clay mineral crystallinity and crystallite size data. Journal of Metamorphic Geology 12, 141-52.

WiLliamson, I. A. 2005. Field Meeting in Lower Kingsdale and Chapel-le-Dale, Ingleton, northwest Yorkshire: Lancashire Group, 9 August 2003. Proceedings of the Geologists' Association 116, 143-7.

Wilson, A. A. \& CoRnwell, J. D. 1982. The Institute of Geological Sciences borehole at Beckermonds Scar, North Yorkshire. Proceedings of the Yorkshire Geological Society 44, 59-88.

Zane, A., SAssi, R. \& GuidotTi, C. V. 1998. New data on metamorphic chlorite as a petrogenetic indicator mineral, with special regard to greenschist-facies rocks. Canadian Mineralogist 36, 713-26. 


\section{Appendix 1. Laboratory methods}

Initial sample crushing was carried out by the BGS Sample Preparation Facility, Keyworth. After removing any surface contaminants with a wire brush, a representative $50 \mathrm{~g}$ portion of each sample was stage-ground, using a Cr-steel tema-mill in 5 second bursts, to pass a $1 \mathrm{~mm}$ sieve. Care was taken to subject the sample to short bursts of milling in order to reduce the chance of over-grinding delicate phyllosilicate grains.

Subsamples of the tema-milled material were then hammer-milled to pass a $0.2 \mathrm{~mm}$ screen and then further micronized to produce a uniform, fine particle-size for powder XRD analysis.

Whole-rock and $b$ cell dimension XRD analyses were carried out using a PANalytical X'Pert Pro series diffractometer equipped with a Co-target tube, $\mathrm{X}^{\prime}$ Celerator detector and operated at $45 \mathrm{kV}$ and $40 \mathrm{~mA}$. Back-loaded powder mounts were scanned from $4.5-85^{\circ} 2 \theta$ at about $2^{\circ} 2 \theta$ /minute.

A further $4 \mathrm{~g}$ portion of the tema-milled material was placed in a boiling tube and distilled water added to a predetermined level. Each sample was then shaken thoroughly, subjected to ultrasound for 5 minutes and allowed to stand for 3 hours. Where flocculation occurred, $0.5 \mathrm{ml}$ of $0.1 \mathrm{M}$ sodium hexametaphosphate was added and the dispersion process repeated. After 3 hours, a nominal $<2 \mu \mathrm{m}$ fraction was removed and centrifuged at maximum speed for 20 minutes. The clear supernatant was then removed and the $<2 \mu \mathrm{m}$ fraction re-dispersed in $\sim 1 \mathrm{ml}$ distilled water with a glass rod and minimal ultrasound. The $<2 \mu \mathrm{m}$ fraction slurry was then pipetted onto the surface of a frosted glass slip and allowed to dry overnight at room temperature.

Each glass slip was analysed using a Philips PW1700 series diffractometer equipped with $\mathrm{Ni}$-filtered $\mathrm{Cu}-\mathrm{K} \alpha$ radiation and operating at $45 \mathrm{kV}$ and $40 \mathrm{~mA}$. The KIs of the samples were calculated from the mean of five scans over the range $7.5-10.5^{\circ} 2 \theta$ at a speed of $0.5^{\circ} 2 \theta /$ minute using the machine conditions recommended by Kisch (1991). The width of the approximately $10 \AA$ peak at half-height was measured using the graphics package within PANalytical's $X$ 'Pert software suite and values were corrected using the standards of Warr \& Rice (1994). Clay mineral assemblages and chlorite crystallinities were determined from longer scans $\left(2-32{ }^{\circ} 2 \theta\right.$ at $0.5^{\circ} 2 \theta /$ minute $)$ of the glass slip mounts. 